\title{
Pope Pius XI and His Scientific Interests
}

$\mathrm{W}$ ITH the lamented death of His Holiness Pope Pius XI on Friday, February 10, the Christian world at large, and the Catholic body in particular, have lost a spiritual leader who will go down in history as a saintly man of courage and character, of kindliness and tolerance, of piety and science.

The duties and interests of a Roman Pontiff are manifold in character. As religious head of the Church, he has to keep, to interpret and to defend the doctrinal and moral teachings of Catholicism. The task of the late Pope in this respect was a difficult one, in view of the social theories and practices of certain totalitarian States. Pius XI placed the whole weight of his authority against individual, social and racial persecution.

As temporal sovereign, the Pope has to consider the political and administrative duties of his exalted position. But in spite of the heavy burden these duties involved, Pius XI never failed to show an active interest in science and its advancement; as a student, he was soon to realize the importance of science not only in a world which is obviously actuated by it, but also for the final shaping of one's philosophical and religious knowledge. As a young scholar, as a curator of the Ambrosian, and afterwards of the Vatican Libraries, as a prelate and finally as a Pope, Pius XI was always assisting the peaceful development of the positive sciences in their various fields of application. For he was convinced that there could be no real incompatibility between science and faith.

The Lateran Treaties, which sealed the peace between the Vatican and the Italian State in 1929, gave the Pope the opportunity of showing in a conclusive manner that he was not only the Pope of peace, but also the Pope of scientific progress. Pius XI took a personal interest in the planning, building and reconstruction of the scientific institutions of his miniature but model State. In November 1930 was opened the new central telephone exchange of the Vatican City ; in the following February, the new electric power station and the new wireless station were inaugurated.

The Pontiff was particularly proud of the powerful wireless station at Castelgondolfo, his summer residence, in which the late Senator Marconi embodied the latest devices. The experiments, the tests and the first messages transmitted from Castelgondolfo in April 1932, were followed with the greatest interest by the scientific world. In fact, special receiving apparatus had to be supplied to authorities abroad to suit the requirements of the ultra-short wave station of Castelgondolfo. Catholics in all parts of the world were thus able to hear in their homes the voice of the Pope himself.

The head of the Church was always ready to co-operate with international scientific organizations. A notable event was the official participation of Vatican delegates to the International Congress of Aeronautics in September 1931 at Budapest. The Pope himself was always ready when his other duties allowed him the time to do so, to receive representatives of learned or technical congresses held in Rome.

The work of the Pontifical institutions in Rome proper was followed with active interest by Pius XI. The inauguration of the new buildings of the Gregorian University in Novem. ber 1930, of the College of the Propagation of Faith in April 1931, of the Art Gallery in October 1932, the collapse of the roof of the Vatican Library and its subsequent reconstruction, and other similar events, gave the Pope many occasions to confirm his support for the achievements of science. The Pope was informed also of the scientific results obtained by the scholars personally in the Pontifical institutions, not only in Rome, but also in the Catholic University of Milan, which has a world-famous school of experimental psychology under Father Gemelli, and in similar institutions abroad.

The crowning example of the Pope's interest in pure science was the reconstitution in 1936 of the Pontifical Academy of Sciences, which is now housed in the Casina Pio IV in the Vatican gardens, through the generosity of Pius XI himself. The Academy, which was known in the past as the Pontificia Accademia dei Nuovi Lincei, now consists of seventy members chosen from among the most distinguished men of science, irrespective of nationality and of religious profession. The British members are Sir Charles Sherrington and Prof. E. T. Whittaker ; the late Lord Rutherford was also a member. His Holiness was present himself at the opening of the new Academy in June 1937.

At the inaugural. meeting of the Pontifical Academy last year, Pope Pius XI paid a personal tribute to the benefits conferred on mankind by the labours of Marconi, whom he honoured with his friendship, and of Hertz, to whose widow now living in exile at Cambridge His Holiness made a personal gift of $£ 250$. Their work, said the Pope, was accompanied by Divine blessing and recalled the words of Schiller: "Soll das Werk den Meister loben, doch der Segen kommt von oben." T. GREENWOOD. 